\title{
THE RESISTANCE OF TEN POTATO VARIETIES TO MECHANICAL INJURY
}

\author{
EsKo SEPPÄNEN \\ Department of Plant Pathology, Agricultural Research Centre
}

Received March 7, 1972

\begin{abstract}
The resistance of 10 potato varieties to mechanical injury was tested. Large intra- and intervarietal variations were detected. The Dutch varieties, Record and Bintje, proved to be the most resistant followed by the Finnish varieties Jaakko and Pito. The amount of severe injuries increased with the age and the size of tubers. Among these varieties no correlation appeared between varietal starch content and injury resistance of tubers.
\end{abstract}

Mechanical damage is a serious problem everywhere in the mechanized growing of seed and table potatoes and has been widely studied. Several investigators have shown that varieties vary considerably in resistance to mechanical injury (LAMPE 1959, ROBERTson 1966, Dambroth 1967, Gall et al 1967, Jacobsen 1969, Gechse 1970). In 1968 a work dealing with the injury resistance of varieties commonly grown in Finland was started. This paper is the first report on that study.

\section{Materials and methods}

In 1968 nine varieties and in 1969 ten varieties were grown in sandy soil in each of two replicates. Fertilization each year was $50 \mathrm{~kg} \mathrm{~N}, 53 \mathrm{~kg} \mathrm{P}$ and $125 \mathrm{~kg} \mathrm{~K}$ per hectare; $\mathrm{pH}$ of the soil was 6.2. The seed potatoes originated from the South Savo Experiment Station and were planted in both of the years at the usual planting time, the end of May. In both years the weather during August was drier than normal and ripening of the crops started by the latter half of August. Tubers were dug by hand.

The starch contents of tubers and tuber size distribution of the varieties are presented in Table 1. Because of the dry August the starch content was about 3 percentage units higher than usual. The tubers remained smaller than usual and only a few tubers were heavier than $110 \mathrm{~g}$. Also varietal differences in size distribution were rather small.

To simulate mechanical injury to tubers during harvesting a simple apparatus using the pendulum principle was constructed. A weight of $1 \mathrm{~kg}$ with a cylindrical pin $(Ø 8 \mathrm{~mm})$ attached to it was fastened to the rim of a wheel. When the weight was released from different heights the rounded surface of the pin hit the tuber with a speed in accordance 
Table 1. Earliness, starch content and size distribution of the tubers of the varieties studied.

\begin{tabular}{|c|c|c|c|c|c|c|}
\hline \multirow[t]{2}{*}{ Variety } & \multirow[t]{2}{*}{ Earliness } & \multirow{2}{*}{$\begin{array}{l}\text { Starch } \\
\text { content } \\
\%\end{array}$} & \multicolumn{4}{|c|}{ Percentage size distribution (by wt.) } \\
\hline & & & $21-50 \mathrm{~g}$ & $51-80 \mathrm{~g}$ & $81-110 \mathrm{~g}$ & $-110 \mathrm{~g}$ \\
\hline Jaakko & early & 18.0 & 28 & 47 & 25 & 0 \\
\hline Sieglinde & , & 15.8 & 41 & 44 & 15 & 0 \\
\hline Bintje & early main crop & 17.0 & 27 & 48 & 25 & 0 \\
\hline Eigenheimer & , & 19.7 & 37 & 45 & 18 & 0 \\
\hline Amyla & late main crop & 20.1 & 34 & 45 & 21 & 0 \\
\hline Olympia & , & 15.9 & 43 & 41 & 15 & 1 \\
\hline Realta & , & 18.1 & 26 & 44 & 30 & 0 \\
\hline Record & , & 17.6 & 23 & 42 & 34 & 1 \\
\hline Pito & late & 20.8 & 25 & 45 & 29 & 1 \\
\hline Valtti & , & 16.5 & 28 & 41 & 30 & 1 \\
\hline
\end{tabular}

with the equation: mass $\times$ acceleration $\times$ height (excluding friction). Three degrees of speed were used, $1.64,1.80$ and $2.00 \mathrm{~m} / \mathrm{sec}$. The tuber was placed so that the pin hit halfway between the stem and bud ends. To imitate the action of a harvester the tuber was allowed to move freely by the force of the hit.

The tubers so treated were examined 2 to 3 months later. They were weighed individually and halved through the point treated. Injuries were classified according to their depth: slight $(<2 \mathrm{~mm})$, moderate $(2$ to $5 \mathrm{~mm})$ and severe $(>5 \mathrm{~mm})$. The method used is quick and suitable for comparison of varieties.

In the calculation of results, tubers analyzed were divided into three size classes, 21 to $50 \mathrm{~g}, 51$ to $80 \mathrm{~g}$ and 81 to $110 \mathrm{~g}$. The means of classes were calculated taking into consideration the weights of tubers. In statistical analysis, Eigenheimer was used as a standard and the deviations of values for other varieties from values for Eigenheimer were tested using the t-test.

\section{Results and conclusions}

Preliminary tests were carried out in 1968 with 9 varieties. The numbers of tubers in each size class tested at each degree of speed were only 40 . The intra-varietal variation was large and therefore the numbers of tubers sampled were insufficient for meaningful statistical analysis. The results obtained, however, were fairly similar to those obtained in 1969 (Fig. 1). The only striking difference was the relationships of the injury resistance of Pito to those of Record, Bintje and Jaakko in the two years.

In 196910 varieties were tested at 3 different times. The first injury tests were conducted on Aug. 14th, the second on Aug. 28th (at the beginning of normal harvest time), and the third after storage to March 14 th. The storage temperature was $5^{\circ} \mathrm{C}$. All treatments were carried out at a temperature of $20^{\circ} \mathrm{C}$.

In spite of large variations within varieties (cf. LAMPE 1959), significant differences between varieties as well as between treatment times were established. In general, the injury-resistance of the varieties decreased with aging of tubers; slight injuries decreased but severe ones increased (Fig. 1). The resistance of the varieties was not correlated with their earliness nor with the starch content of their tubers (Table 1 and Fig. 1). 

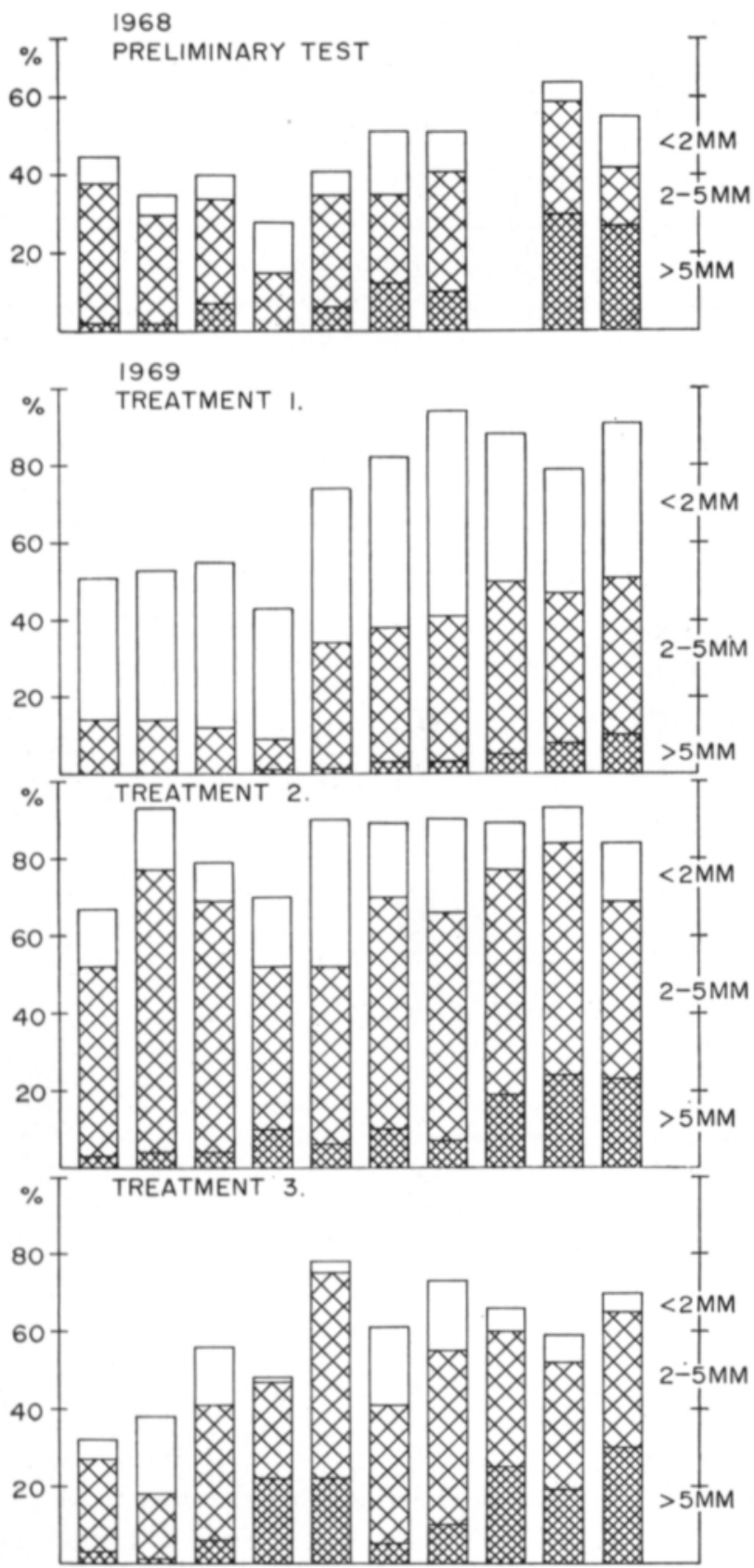

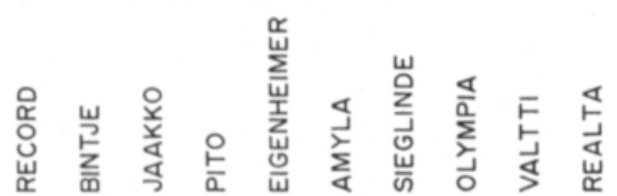

Fig. 1. Percentages of slight, moderate, and severe damage to different varieties in a preliminary test in 1968 and after application of injury treatments on three dates (Aug. 14, Aug. 28 and March 14) in 1969-70. Means were calculated aritmethmetically from size class injury means.

Kuva 1. Lievien, kohtalaisten ja pahojen vioitusten prosenttiset osuudet eri lajikkeiden mukuloissa valmistavassa kokeessa v. 1968 sekä kolmessa eri käsittelyssä (14. 8., 28. 8. ja 14. 3.) v. 1969-70. Tulokset ovat kolmen iskunopeuden ja kolmen suuruusluokan keskiarvoja. 
Considering the severity of defects and all three times of treatment, the injury resistance of Record, Bintje, Jaakko and Pito was significantly higher than that of Eigenheimer and the other varieties. The resistance of Realta was significantly lower than that of Eigenheimer. The rapid decrease in injury resistance in Pito and Eigenheimer with tuber maturity and in storage is striking and requires further examination.

The present results are similar to the findings of other workers. The high resistance of Record has been reported by Robertson (1966) and that of Bintje by DAMBroth (1967), Gall et al (1967) and Gechse (1970). According to Jacobsen (1969) the injury resistance of Bintje is only moderate. The susceptibility to injury of Sieglinde has been previously reported by Lampe (1959), Dambroth (1967) and Jacobsen (1969). According to DamBROTH (1967) Amyla and Olympia are more injury-resistant than Sieglinde but this is not corroborated by the results of the present tests.

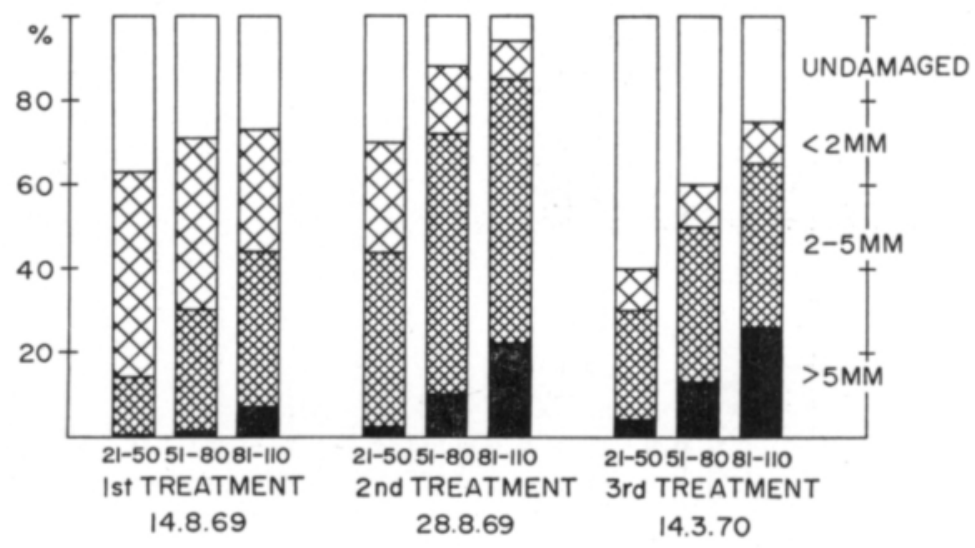

Fig. 2. Percentage distribution of slight, moderate and severe damage to tubers of different size classes and different treatment times. Means of averages of 10 varieties.

Kuva 2. Lievien, kohtalaisten ja pahojen vioitusten prosenttiset osuudet eri kokoluokissa ja eri käsittelyissä; tulokset ovat 10 lajikkeen keskiarvoja. (Treatment $=$ käsittely, undamaged $=$ vioittumattomat).

The relation of tuber size to injury is shown in Fig. 2 in which all varieties have been averaged. Large tubers were more susceptible to injury than smaller ones (cf. Lööw 1960). Varieties, such as Record, which have a higher percentage of large tubers will tend to be more susceptible to mechanical injury than smalltubered varieties. This is not indicated in Fig. 1 because the injury values shown are arithmetic means of the average injury of the three tuber-size classes used and thus do not take into consideration the percentage of tubers in each size class. 


\title{
REFERENCES
}

Dамвrотн, M. 1967. Der Einfluss von Umwelt und pflanzenbaulichen Massnahmen auf die spezifische Widerstandsfähigkeit von Kartoffelknollen gegen mechanische Belastungen. Diss. 149 p. Giessen.

Gall, H. \& Lambrecht, P. \& Fechter, E. 1967. Erste Ergebnisse mit dem Rückschlagpendel zur Bestimmung der Beschädigungsempfindlichkeit von Kartoffelknollen. Eur. Potato J. 10: 272-285.

Gechse, M. 1970. Chemish-analytische und histologische Untersuchungen über die Ursacher der Beschädigungsempfindlichkeit der Kartoffel. Diss. 76 p. Göttingen.

JACobsen, B. 1969. Further investigations on tuber damage resistance of different potato varieties. Proc. 4th Trienn. Conf. EAPR, Brest: 242-243.

LAMPE, K. 1959. Entwicklung und Erprobung einer Methode zur Bestimmung der Widerstandsfähigkeit von Kartoffelknollen gegen Beschädigungen. Diss. 125 p. Bonn.

Lööw, H. 1960. Beurteilung von Beschädigungen an Kartoffelknollen. Kann man nur eine Grössenfraktion beurteilen und dadurch die Beurteilung vereinfachen? Eur. Potato J. 3: 283-295.

Robertson, I. M. 1966. Effect of season and variety on the susceptibility of potato tuber to damage. Proc. 3rd Trienn. Conf. EAPR, Zürich: 266-267.

\section{SELOSTUS}

\section{PERUNALAJIKKEIDEMME KÄSITTELYNKESTÄVYYDESTÄ}

\author{
EsKo SEPPÄNEN
}

Kasvitautien tutkimuslaitos, Maatalouden tutkimuskeskus

Kymmenen meillä yleisesti viljellyn perunalajikkeen käsittelynkestävyyttä tutkittiin yksinkertaisen heiluriperiaattelle konstruoidun laitteen avulla. Alustava koe tehtiin v. 1968 ja varsinainen 3 käsittelyaikaa käsittävä tutkimus v. 1969-70. Käsiteltävät mukulat oli kasvatettu yhdenmukaisesti kahtena kerranteena, nostettu hellävaraisesti ja käsitelty samassa lämpötilassa. Kolmea iskunopeutta (1.64, 1.80 ja $2.00 \mathrm{~m} / \mathrm{sek}$.) käytettiin. Mukulat punnittiin ja analysoitiin yksitellen. Näin ollen tulokset oli mahdollista laskea kussakin kokoluokassa painotettuina keskiarvoina. Esitetyissä tuloksissa (kuva 1) on kunkin lajikkeen mukulakokojakautuma eliminoitu, minkä vuoksi suurimukulainen lajike, kuten esim. Rekord on alttiimpi kuin mitä tulokset osoittavat.

Sekä lajikkeiden sisäinen että välinen vaihtelu oli suuri. Lisäksi oli todettavissa, että pahojen vioitusten (yli $5 \mathrm{~mm}$ ) osuus suureni mukuloiden iän ja painon lisääntyessä. Ottaen huomioon kaikki kuvassa 1 esitetyt tulokset ovat Record ja Bintje kestävimmät, seuraavina ovat Jaakko ja Pito. Ero näiden neljän ja muiden lajikkeiden välillä oli merkitsevä. Eigenheimer, Amyla ja Siikli (Sieglinde) olivat suunnilleen yhtä kestäviä, Olympia, Valtti ja Realta niitä alttiimpia. Yllättävää on Pidon ja Eigenheimerin alttiuden suuri lisääntyminen varastoinnin aikana.

Saadut tulokset ovat melko yhtäpitävät ulkomaisten tutkimusten kanssa, joissa Bintje ja Rekord on todettu kestäviksi sekä Amyla, Olympia ja Siikli alttiiksi. 